\title{
CONVERSION OF FORMER INDUSTRIAL PORTS INTO TOURIST ATTRACTIONS. HAS INTEGRATION BEEN ACHIEVED?
}

\author{
Daniel Barrera-Fernandez ${ }^{1}$ \\ Marco Antonio Hernandez-Escampa ${ }^{2}$
}

\begin{abstract}
The transformation of redundant port facilities has become a priority in many cities willing to attract a larger number of tourists. From Baltimore's successful initiative to Barcelona's dissemination of the model in Europe, one city after another have implemented the same examples with few variations. The objective of the research is to analyze the renovation of former industrial ports in two medium-size cities: Plymouth and Malaga, focusing on whether the projects have matched the initial objectives to turn the facilities into tourist attractions as well as to integrate them in the city life. The methodological process is based on a comparative analysis of five different issues, namely external accessibility, internal mobility, activities, heritage protection and general integration in the urban context. The research process has ended up in the production of comparative maps. Major differences between both examples can be found in the integration of heritage, both cultural and natural, the consolidation of a mix of uses and the existence of physical barriers between the port and the rest of the city.
\end{abstract}

Key words: urban tourism, cruise facilities, waterfront, heritage, regeneration

\section{THE TOURIST USE OF A SINGULAR PIECE: THE WATERFRONT}

The regeneration of the waterfront for tourism and leisure uses is a solution to the decline of port facilities.In general, all projects of this kind follow the same models, from the first interventions in Baltimore and other cities in USA, through their adaptation to European cities to their current globalization (Ward, 2006). According to Andrade Marqués and Blasco López (2012), three phases can be distinguished in port regerenation. In the first phase in the 1960s-1970s, only leisure activities were established. In the 1980s residences were introduced. In the 1990s, spectacular architectural projects were developed coinciding with mega-events. Finally, in the 21 st century, factors of competitiveness are differentiation and maintainance of the local port identity.

A common negative effect of these projects is that they contribute to the substitution of traditional port activities and loss of heritage assets (Williams, 2004). Some of the difficulties in planning these spaces are the existence of physical barriers between the port and the rest of the city, the participation of various government agencies (Alemany Llovera, 2005) and the increasing security requirements (Estrada Llaquet, 2006). There is a substantial difference in the presence of built heritage depending on whether the port has a military or commercial origin (Pinder \& Smith, 1999). In addition, there is sometimes a delicate natural heritage closely dependent on built structures (Howard \& Pinder, 2003). Finally, integration of non-material values has to be considered to achieve a sustainable development (Van Hooydonk, 2009).

\footnotetext{
${ }^{1}$ Associate Professor, Department of Architecture, Faculty of Architecture, University of Guanajuato, Guanajuato, Mexico.

${ }^{2}$ Associate Professor, Department of Architecture, Faculty of Architecture, University of Guanajuato, Guanajuato, Mexico.
} 


\section{COMPARATIVE ANALYSIS OF THE TOURIST REGENERATION OF PORTS IN PLYMOUTH AND MALAGA}

\section{Introduction to both cases}

Sea and port activities are crucial to understand the history, urban development and character of Plymouth (England, UK). Unbuilt areas for military reasons led to the open spacesthat arenowadays the symbolic image of the city. The Army built its facilities in areas of difficult access by land but suitable for naval function and, after losing its strategic interest, some of these sectors have been integrated into urban life. These features have made Plymouth's waterfront a relatively little changed area, with great heritage value, making it a major tourist resource.

On the other side, the waterfront in Malaga (Andalusia, Spain) is the result of a series of profound changes in the coastline. The port has been extendedthrough land reclamation and the city has taken over the former coastal areas. During the twentieth century the city and the port evolved independently, gates and fences were installed and high capacity roads were created, acting as a physical barrier. Fisheries and port activities were no longer visible from the city and Malaga's maritime character was lost.

Currently, Malaga's waterfront has two distinct parts. The port is located in the city centre, divided into a touristsection and anindustrial area. The rest of the waterfront is made up of urban highways, sea promenades and sandy beaches with residential uses, with only two exceptions to this rule: the former fishermen's neighborhood of Pedregalejo and the former seaside resort of Baños del Carmen (Barrera-Fernandez, 2012).

\section{External accessibility}

Unlike other cities, in Plymouth there is no road or rail infrastructure acting as a barrier between the waterfront and the rest of the city. Historical reasons are the difficult topography, military uses and the twisting shape of the coastline. Apart from them, tourist plans and urban policies have repeatedly decided not to intervene aggressively in order to preserve this unique space. Today, the waterfront is only accessible by secondary roads and the parking area is very limited, being far more practical to reach it by bus, taxi, bike or on foot.

Malaga has a main road acting as a barrier between to the waterfront. While regeneration of the port was being carried out to increase tourist activities, some proposals were suggested to mitigate the barrier, but none of theme was finally developed. Even the longterm demand of removing the fence between the port and the city has been accomplished only partially.In fact, the solution applied was in the opposite direction, an underground car parkand a new traffic lane were created, thus increasing traffic significantly. The physical separation of the port and the rest of the city is just the implementation of the division and lack of coordination between the different agencies intervening in the port: City Council, Port Authority, Andalusian Government and Spanish Government. 


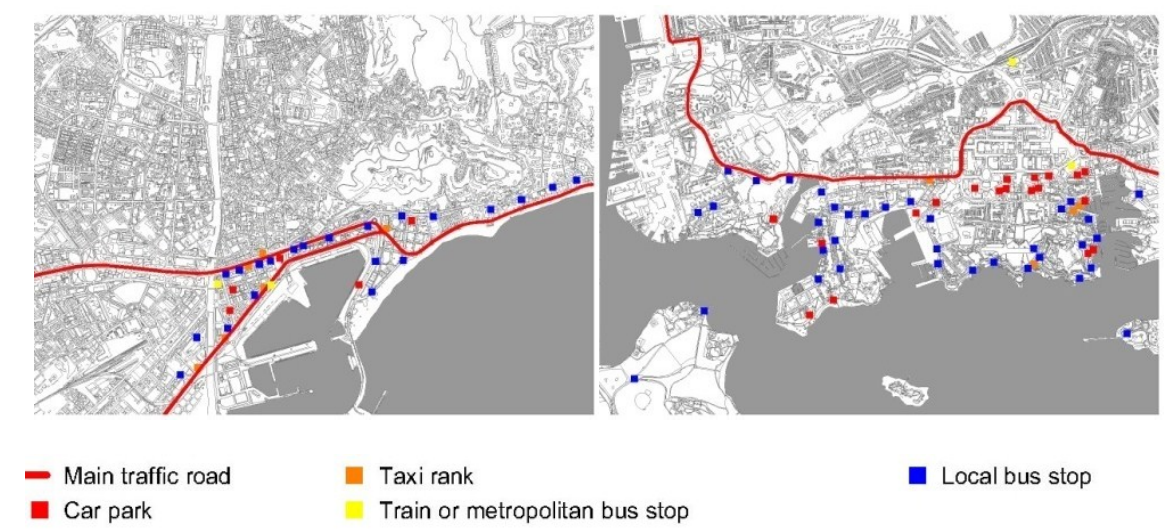

Fig. 1. External accessibility to the waterfronts of Plymouth and Malaga. Source: BarreraFernandez, D.

\section{Internal mobility}

In Plymouth's waterfront there are several ferry connections, from those serving its neighborhoods to those connecting with France and Spain. In general, bike paths are shared with pedestrians or vehicles. In particular, the South West Coast Path National Trail goes all along the waterfront. Apart from it, pedestrians have access to the waterfront through paths and stairs except in military and industrial areas. Granting public access has been a priority in all urban plans and regeneration policies since the 1990s.

In the case of Malaga, pedestrian mobility is possible in the beach areas but problems appear when trying to reach the port. In the tourist section, pier 1 is accessible only in the commercial sector, while in pier 2 two levels have been created and only cruise passengers have access to the coastline. Bicycles have even more restrictions than pedestrians, since there are no bike lanes along the waterfront. In addition, cycling is prohibited in the nontourist section of the port. Pedestrian mobility and cycling havebeen made more difficult after the renovation of the port to attract tourist activities. Fences, prohibition signs and security cameras have multiplied to prevent visitors from leaving the tourist sector. As a result, public access is forbidden to the stretches from which the best views of the waterfront can be enjoyed.

\section{Activities}

In relation to activities, Plymouth's waterfront is currently characterized by a mix of uses and a coexistence of activities that tend to be segregated elsewhere. A variety of uses has been an objective inall kinds ofregeneration-related policies since the 1990s, as reflected in documents such as Tomorrow's Waterfront (Plymouth City Council, 1990), the Local Plan First Alteration (Plymouth City Council, 1996), the Vision for Plymouth (MBM Arquitectes, AZ Urban Studio, 2003) and The Plymouth Local Economic Strategy 2006 2021 \& Beyond (Plymouth City Council, 2011). Although port activities such as shipyards, ancillary industries, freight and fishing do not have the weight they had before, regeneration policies emphasize the importance to keep them in order to diversify the economy, reducing the overreliance on tourist and commercial activities. 
Currently, the city offers a wide range of berths and marinas along the coastline. Tourist and commercial uses have been enhanced in three sensitive areas: Royal William Yard, Sutton Harbour and The Hoe. In all of them the variety of shops, restaurants and services has been expanded although with different results. Royal William Yard has been fully restored, however, the place lacks the desired multifunctionality and has a uniform picturesque appearance. The Hoe has managed to retain its character as an open space and Sutton Harbour has made an effort to keep its mix of residences and tourist uses, although not without tensions. The city's tourist policies have put the emphasis on the development of the waterfront in a sustainable way, thinking about a future in harmony with the environment and the aspirations of the local community. Nevertheless, this search for a consensus has made some operations excessively slow, like the cases of the unrealised projects to reuse Drake's Island or the new infrastructure for cruise passengers in Millbay.

Malaga's waterfront can be divided in two main sectors: sandy beaches and the port. Although beaches are officially considered as open spaces, they are being increasingly occupied by restaurants and hammocks. In contrast to the case of Plymouth, regeneration of Malaga's waterfront to promote tourist and commercial activities has not been balanced with a recognition of exisiting port activities and there has not been an effort to make them more present in the city's daily life. In fact, they have been hidden away from the tourists' gaze.

In general terms, Malaga's waterfront is characterized by segregation of activities. Each section is designed to accommodate only one activity. Moreover, there are no activities to attract citizens unless they act as tourists. As a result, social mix and spontaneity are unresolved matters. To this artificiality, specific port regulations have contributed. As an example, it is forbidden to sell or consume food and beverages outside restaurants, playing in water sources is prohibited and permission is required to play music or perform artistic or cultural events.

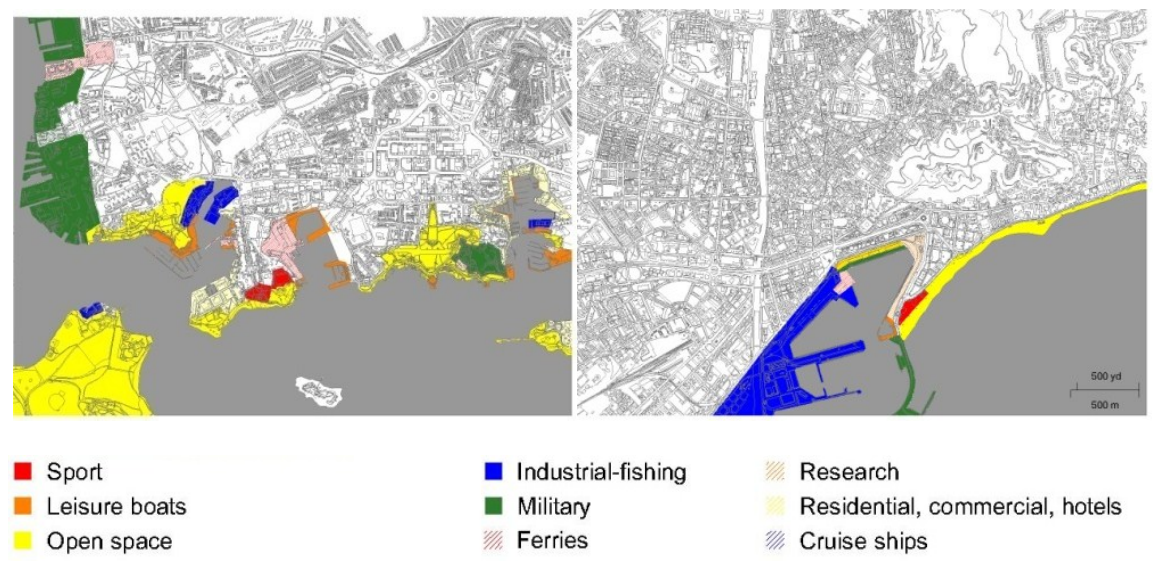

Fig. 2. Land uses on the waterfront of Plymouth and Malaga. Source: Barrera-Fernandez 


\section{Heritage protection}

As mentioned above, tourist plans in Plymouth's waterfront always begin with a recognition of the cultural, natural and landscape value of this environment and their preservation is a main objective. A positive feature in this regard is that heritage protection is not limited by ownership or administrations involved, resulting in a large amount of listed military sites in the waterfront. In relation to port heritage, a wide range of assets have been listed, such as docks, bollards, walls, warehouses and facilities of all kinds. In addition, there is a listed wreck. Regarding protected urban areas, there are four Conservation Areas includingwaterfront sections within their limits.

Furthermore, Plymouth's waterfront concentrates a number of protected natural sites, since it serves as the habitat of several communities of plants, fish and birds, some of them endangered. Therefore, interventions carried out in the waterfronthave to assess their impact on marine life (Plymouth City Council, 2007). Finally, non-tangible values associated with the port have a leading role in the city, in aspects such as the cultural life, scientific research centres and marketing strategies. The new city's brand itself of "Plymouth, Britain's Ocean City" states the close relationship that this city keeps with the sea.

On the other side, Malaga's waterfront is very poor in terms of cultural heritage and protected natural areas. One factor that explains this situation is land reclamation, which has made former port facilities lose its location close to the sea. Another reason is that the Andalusian Government does not have the power to protect heritage assets linked to Staterun services (Act 16/1985). As a result, the entire coastline presents a great artificiality, with annual supply of sand, which has serious consequences for marine life. Furthermore, the port belonged to the central Conservation Area until 2012, when it was excluded of the new delimitationand nowadays the only listed asset is the Virgen del Puerto chapel. This lack of protection resulted in the destruction of a significant amount of industrial heritage assets when the port was regenerated to attract cruise ships, losing the grain silo, warehouses, cranes, port facilities, pavements and townscape elements.

\section{General integration in the urban context}

Suming up all the aspects analyzed, it can be considered that Plymouth's port is well integrated with the rest of the city, since access from other neighborhoods is relatively easy, there are no inner barriers, there is a continuity of the urban fabric, the port is socially inclusive, it has an intense daily activity and regulations are as restrictive or permissive than in other parts of the city. The only areas in which unauthorized access is forbidden are military sites, shipyards and fishing facilities. Some areas such as marinas and leisure facilities have a very specific use but they are accessible anyway. Open spaces have an inclusive design to allow mix of activities and users.Only Drake's Island is a pending task since it remains abandoned and is only accessible by private boat.

In the case of Malaga, the port's integration needs further improvement. Beach areas are fully accessible but private occupation is increasingly limiting public use. The tourist sector of the port can only be accessed partially. Entry to marinas and cruise berths is banned for general public. The commercial area has been designed as an open-air shopping centre, where there is no space for activities not related to consumption. The closest dock 
to the city centre has been divided into two parts, being the waterfront reserved only for luxury cruise ships. In the tourist and commercial area users are encouraged to move in a limited area and to act in accordance with the intended uses, thus creating an atmosphere of artificiality and exclusion, more similar to the one of a shopping centre than to an open space. In fact, since the port was reconverted to a tourist attraction, new fences and controls have been installed, separating the port even more from the city. In Malaga's waterfront there is a lack of long-term vision that results in rigid parts, unconnected to each other and impossible to cross without authorization. In addition, recognition of the port's non-material values is still pending, as well as the integration of port activities in the city's daily life and identity.

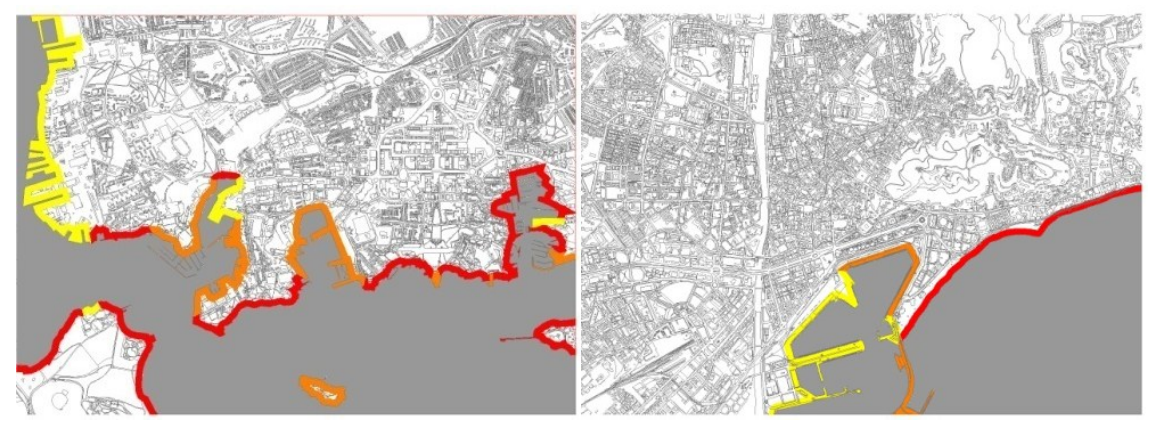

Fig. 3. Integration of the waterfront with the rest of the city in Plymouth and Malaga. Source: Barrera-Fernandez, D.

\section{CONCLUSIONS}

This research has presented two models of renovation of former industrial ports to attract further tourist and commercial activities. In Plymouth's example, tourist activities have been developed without losing its mix of uses. On the other hand, Malaga has neglected social inclusion and public access in favor of a project fully devoted to cruise ships and shopping. Several keys arise from the comparative analysis for cities aiming at regenerating redundant port facilities in a sustainable way. A priority is to grant accessibility from the rest of the city, which has not always an easy solution due to the existence of physical barriers such as roads or railways, thus a long-term vision is needed where urban plans and economic delivery strategies play necessarily a main role. Secondly, a diversity of users, not only tourists, needs to be achieved. In this regard, internal mobility is recommended to be granted by public transport, bike or pedestrian walkways both along the coastline and perpendicular to the different specialized sections of the waterfront.

Focusing only on tourist-related activities leads to a lack of social mix and underused areas, thus incorporation of other uses more related to the city's daily life is crucial to grant activity around the clock. Finally, an extended risk in reconversion of former industrial ports is the development of tourist attractions very similar one to another. Distinction can be achieved by integration of built heritage, especially industrial assets, the natural heritage represented by the ecosystems coexisting with built structures and non-material values, closely related the role that the port has in the city's history and identity. 


\section{REFERENCES}

1. Act 16/1985 of Spanish Historic Heritage. Art. 6b.

2. Alemany Llovera, J. (2005). El frente marítimo, entre el urbanismo y la planificación portuaria. Portus, 10, 2-3.

3. Andrade Marqués, M.J., Blasco López, J. (2012). Puerto-ciudad. Estudio comparativo de buenas prácticas. Malaga: Servicio de Programas Europeos.

4. Barrera-Fernandez, D. (2012). Los Baños del Carmen a traves de los planes y proyectos que intervinieron en su creacion y que proponen su regeneracion. eDap. Documentos de Arquitectura y Patrimonio, 5, 42-51.

5. Estrada Llaquet, J.L.(2006). Las exigencias de protección obligan a un cambio cultural de la explotación portuaria y de las relaciones puerto-ciudad. Portus, 11, 12-17.

6. Howard, P., Pinder, D. (2003). Cultural heritage and sustainability in the coastal zone: experiences in south west England. Journal of Cultural Heritage, 4, 57-68.

7. MBM Arquitectes, AZ Urban Studio. (2003). A Vision for Plymouth. Final Copy.

8. Pinder, D., Smith, H. (1999). Heritage and change on the naval waterfront: opportunity and challenge. Ocean \& CoastalManagement, 42, 861-889.

9. Plymouth City Council. (1990). Tomorrow's waterfront: a strategy for Plymouth waterfront.

10. Plymouth City Council. (1996). City of Plymouth Local Plan 1991-2001. First Alteration.

11. Plymouth City Council. (2007). Local Development Framework, Core Strategy.

12. Plymouth City Council. (2011). Plymouth Local Economic Strategy 2006 - 2021 \& Beyond.

13. Van Hooydonk, E. (2009). Port city identity and urban planning. Portus, 18, 16-23.

14. Ward, S.V. Cities are fun!.(2006). Inventing and spreading the Baltimore model of cultural urbanism. In: Monclús, J., Guardia, M. (eds). Culture, urbanism and planning. Aldershot: Ashgate. 271-286.

15. Williams, R.J. (2004). The anxious city. Oxon and New York: Routledge. 